\title{
FAKTOR-FAKTOR YANG BERHUBUNGAN DENGAN PERILAKU SEKS BEBAS PADA MAHASISWA DI TANGERANG SELATAN
}

\author{
Lela Kania, Tri Okta \\ Sekolah Tinggi Ilmu Kesehatan Kharisma Persada \\ Tangerang Selatan, 15417 \\ E-mail: lila.kania@gmail.com
}

\begin{abstract}
ABSTRAK
Pada data yang bersumber dari survei yang dilakukan oleh Komite Perlindungan Anak Indonesia (KPAI), dan Kementrian Kesehatan (Kemenkes), pada Oktober 2013 memaparkan bahwa sekitar 62,7\% remaja di Indonesia telah melakukan hubungan seks di luar nikah 20\% dari 94.270 perempuan yang mengalami hamil di luar nikah juga berasal dari kelompok usia remaja dan $21 \%$ diantaranya pernah melakukan aborsi. Tujuan penelitian ini yaitu untuk mengetahui faktor-faktor yang berhubungan dengan perilaku seks bebas pada mahasiswa di Tangerang Selatan. Rancangan penelitian yang digunakan adalah metode survei analitik dengan pendekatan cross sectional Hasil penelitian ini yaitu terdapat hubungan jenis kelamin dengan perilaku seks bebas pada mahasiswa di Tangerang Selatan dengan hasil analisis data pada tabel silang maka didapatkan nilai $P$-Value $=0.039$ dari kemaknaan $\alpha=0.05$ maka $P$-Value $<\alpha$. Selain itu terdapat hubungan sikap dengan perilaku seks bebas pada mahasiswa di Tangerang Selatan dengan hasil analisis data pada tabel silang maka didapatkan nilai $P$-Value $=0.000$ dari kemaknaan $\alpha=0.05$ maka $P$ Value $<\alpha$. Kesimpulan dari penelitian ini yaitu faktor-faktor yang berhubungan dengan perilaku seks bebas pada mahasiswa di Tangerang Selatan adalah jenis kelamin dan sikap mahasiswa.
\end{abstract}

Kata Kunci : perilaku seks bebas, aborsi

\begin{abstract}
In the data sourced from a survey conducted by the Indonesian Child Protection Committee (KPAI) and the Ministry of Health (MoH), in October 2013 revealed that approximately $62.7 \%$ of teenagers in Indonesia have had sex outside of marriage $20 \%$ of 94,270 women pregnant outside of marriage also comes from teenage age group and $21 \%$ have ever had an abortion. The purpose of this study is to determine the factors associated with free sex behavior in college students in South Tangerang. The research design used is analytic survey method with cross sectional approach. The result of this research is sex relationship with free sex behavior in students in South Tangerang with the result of data analysis on cross table then got value $P$-Value $=0.039$ from significance $\alpha=0.05$ then $P$-Value $<\alpha$. In addition there is a relationship attitude with free sex behavior in students in South Tangerang with the results of data analysis on the cross table then got the value of P-Value $=0.000$ of significance $\alpha=0.05$ then P-Value $<\alpha$. The conclusion of this research are factors related to free sex behavior in students in South Tangerang is gender and student attitude.
\end{abstract}

Keywords: free sex behavior, abortion 


\section{PENDAHULUAN}

\begin{abstract}
Pengertian Pergaulan Bebas diambil karena arti dari pergaulan dan bebas, pengertian pergaulan adalah merupakan proses interaksi antara individu atau individu dengan kelompok. Sedangkan bebas adalah terlepas dari kewajiban, aturan, tuntutan, norma agama dan norma kesusilaan. Pergaulan berpengaruh terhadap pembentukan kepribadian seorang individu baik pergaulan positif atau negatif. Kejadian pergaulan bebas yang terjadi di kalangan remaja banyak berasal dari eksploitasi seksual pada media yang ada di sekeliling kita. Eksploitasi seksual dalam video, majalah, televisi dan film-film ternyata mendorong para remaja untuk melakukan aktivitas seks secara sembarangan diusia muda. Dengan melihat tampilan atau tayangan seks di media, para remaja itu beranggapan bahwa seks adalah sesuatu yang bebas dilakukan oleh siapa saja,dimana saja.
\end{abstract}

Hasil penelitian Yayasan Kesuma Buana, menunjukkan bahwa sebayak $10.3 \%$ dari 3,594 remaja di 12 kota besar di Indonesia telah melakukan hubungan seks bebas, berdasarkan penelitian di berbagai kota besar di Indonesia, sekitar 20 hingga
$30 \%$ remaja mengaku pernah melakukan hubungan seks bebas. Ini di mungkinkan karena longgarnya kontrolan orang tua pada mereka. Pakar seks juga spesialis Obstetri dan Ginekologi Dr. Boyke Dian Nugraha di Jakarta mengungkapkan, dari tahun ke tahun data remaja yang melakukan hubungan seks bebas semakin meningkat.

Data tersebut sejalan dengan survei Badan Kependudukan dan Keluarga Berencana Nasional (BKKBN) pada tahun 2010, 52\% remaja Medan sudah melakukan seks bebas yang berdampak kepada terjangkitnya penyakit Infeksi Menular Seksual (IMS), Ini artinya setiap tahunnya fenomena seks bebas atau perilaku seks pra-nikah yang dilakukan remaja terus mengalami peningkatan bahkan menambah korban penularan PMS (Penyakit Menular Seks).

Perilaku seks bebas yang melanda remaja sering kali menimbulkan kecemasan para orang tua, pendidik, pemerintah, para ulama dan lain-lain. Untuk itu, perlu dilakukan penanganan sedini mungkin untuk menghindari hal-hal yang tidak diinginkan seperti aborsi. Aborsi 
adalah dampak paling berbahaya dari seks bebas, yang dari tahun ke tahun semakin banyak dilakukan remaja di Indonesia. Sebanyak $62,7 \%$ remaja SMP tidak perawan dan $21,2 \%$ remaja mengaku pernah aborsi. Perilaku seks bebas pada remaja tersebar di kota dan desa pada tingkat ekonomi kaya dan miskin.

Pada data yang bersumber dari survei yang dilakukan oleh Komite Perlindungan Anak Indonesia (KPAI), dan Kementrian Kesehatan (Kemenkes), pada Oktober 2013 memaparkan bahwa sekitar 62,7\% remaja di Indonesia telah melakukan hubungan seks di luar nikah $20 \%$ dari

\section{METODE}

Jenis penelitian yang digunakan adalah eksplanatori (penjelasan), yang bertujuan untuk mengetahui faktorfaktor yang berhubungan dengan perilaku seks bebas pada mahasiswa di Tangerang Selatan.

Rancangan penelitian yang digunakan adalah metode survei analitik dengan pendekatan cross sectional yaitu rancangan epidemiologi yang mempelajari hubungan penyakit dan paparan (faktor penelitian) status paparan dan penyakit
94.270 perempuan yang mengalami hamil di luar nikah juga berasal dari kelompok usia remaja dan $21 \%$ diantaranya pernah melakukan aborsi. Lalu pada kasus terinfeksi HIV dalam rentang 3 bulan sebanyak 10.203 kasus, $30 \%$ penderitanya berusia remaja. Fenomena itu sebenarnya merupakan lanjutan dari begitu banyak kemudahan yang diterima anak-anak, bahkan yang berasal dari para orang tua mereka sendiri, untuk mengakses konten-konten porno di medsos via gadget yang diperoleh pada usia terlalu dini tanpa dibekali aturan yang tepat dalam penggunaannya.

dalam waktu serentak pada individuindividu dari populasi tunggal, pada satu saat atau tahun yang sama.

Populasi atau universe adalah keseluruhan dari satuan-satuan atau individu-individu yang karakteristiknya hendak diteliti. Populasi dalam penelitian ini adalah jumlah seluruh mahasiswa/mahasiswi yang ada di Tangerang Selatan.

Sampel adalah sebagian dari populasi yang karakteristiknya hendak diteliti atau terpilih dalam penelitian. 
Jumlah sampel untuk survei cepat Tangerang Selatan.

ditentukan sebanyak 210 mahasiswa di

\section{HASIL}

\section{Karakteristik Responden}

a. Jenis kelamin

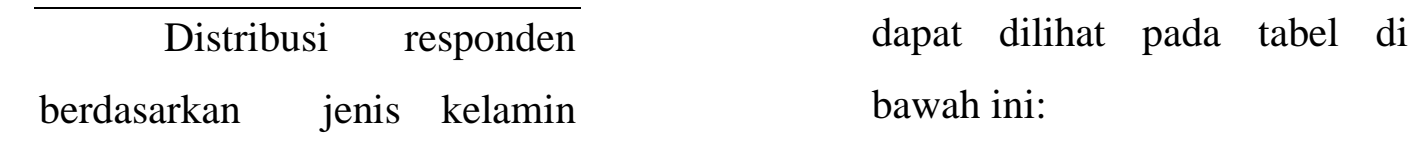

Tabel 1. Distribusi Responden menurut Jenis kelamin mahasiswa di

\begin{tabular}{lcc} 
& Tangerang Selatan & \\
\hline \multicolumn{1}{c}{ Jenis Kelamin } & $\mathrm{N}$ & $\%$ \\
\hline Laki-Laki & 53 & 25.24 \\
\hline Perempuan & 157 & 74.76 \\
\hline Total & 210 & 100 \\
\hline
\end{tabular}

$\begin{array}{llll}\text { Berdasarkan tabel } 1 & \text { orang responden }(25.24 \%) & \text { dan } \\ \text { dapat dilihat bahwa jenis } & \text { perempuan berjumlah } & 157 \\ \text { kelamin laki-laki berjumlah } 53 & \text { orang responden }(74.76 \%) .\end{array}$

b. Usia

Responden yang diteliti untuk kategori usia remaja yang adalah 210 responden yang diteliti didapatkan hasil untuk sudah dipilih secara acak dari rata-rata usia 19 tahun populasi mahasiswa yang ada sedangkan median usia 20 di Tangerang Selatan. tahun.

Berdasarkan hasil perhitungan 


\section{Faktor-faktor yang berhubungan dengan Perilaku Seks Bebas}

a. Hubungan antara jenis

\section{kelamin dengan perilaku}

seks bebas

Berikut tabel silang dengan perilaku seks bebas hubungan antara jenis kelamin antara lain :

Tabel 2. Tabel Silang Hubungan Antara Jenis Kelamin Dengan Perilaku Seks Bebas di Tangerang Selatan

\begin{tabular}{ccccccc}
\hline \multirow{2}{*}{ Jenis kelamin } & \multicolumn{4}{c}{ Perilaku seks bebas } & \multicolumn{2}{c}{ Total } \\
\cline { 2 - 6 } & \multicolumn{3}{c}{ Ya } & Tidak & & $\%$ \\
\cline { 2 - 6 } & $\mathrm{N}$ & $\%$ & $\mathrm{~N}$ & $\%$ & $\mathrm{~N}$ & $\%$ \\
\hline Laki-laki & 5 & 9.43 & 48 & 90.57 & 53 & 100.00 \\
\hline Perempuan & 3 & 1.91 & 154 & 98.09 & 157 & 100.00 \\
\hline \multicolumn{4}{c}{$P$-Value $=0.039$} \\
\end{tabular}

Berdasarkan hasil penelitian dapat diketahui bahwa responden yang berjenis kelamin laki-laki dan pernah melakukan seks bebas sejumlah $5 \quad(9.43 \%)$ dan responden yang berjenis kelamin laki-laki dan tidak pernah melakukan seks bebas sejumlah $48 \quad(90.57 \%)$. Sementara responden yang berjenis kelamin perempuan dan pernah melakukan seks bebas sejumlah 3 (1.91\%), responden yang berjenis kelamin perempuan dan tidak pernah melakukan seks bebas sejumlah 154 (98.09\%). Hasil analisis data pada tabel diatas maka didapatkan nilai $P$ Value $=0.039$ dari kemaknaan $\alpha=0.05$, maka $P$-Value $<\alpha$ yang artinya terdapat hubungan yang bermakna antara jenis kelamin terhadap perilaku seks bebas. 
b. Hubungan antara usia dengan perilaku seks bebas

Berikut tabel silang perilaku seks bebas antara hubungan antara usia dengan lain:

Tabel 3. Tabel Silang hubungan antara usia dengan perilaku seks bebas di Tangerang Selatan

\begin{tabular}{ccccccc}
\hline \multirow{2}{*}{ Usia } & \multicolumn{4}{c}{ Perilaku seks bebas } & \multicolumn{2}{c}{ Total } \\
\cline { 2 - 6 } & $\mathrm{N}$ & $\%$ & $\mathrm{~N}$ & $\%$ & $\mathrm{~N}$ & $\%$ \\
\hline $1(17-19$ thn $)$ & 3 & 3.90 & 74 & 96.10 & 77 & 0 \\
\hline $2(20-24$ thn $)$ & 5 & 3.76 & 128 & 96.24 & 133 & 100.00 \\
\hline \multicolumn{6}{c}{$P$-Value $=1.000$} \\
\hline
\end{tabular}

Berdasarkan hasil penelitian dapat diketahui bahwa responden yang berusia 17-19 tahun dan pernah melakukan seks bebas sejumlah $3(3.90 \%)$ dan responden yang berusia 17-19 tahun dan tidak pernah melakukan seks bebas sejumlah $74 \quad(96.10 \%)$. Sementara responden yang berusia 20-24 tahun dan pernah melakukan seks bebas sejumlah $5 \quad(3.76 \%)$ dan responden yang berusia 20-24 tahun dan tidak pernah melakukan seks bebas sejumlah 128 (96.24\%). Hasil analisis data pada tabel diatas maka didapatkan nilai $P$ Value $=1.000$ dari kemaknaan $\alpha=0.05$, maka $P$-Value $>\alpha$ yang artinya tidak terdapat hubungan yang bermakna antara usia terhadap perilaku seks bebas.

\section{c. Hubungan antara pengetahuan dengan perilaku seks bebas}

Berikut tabel silang hubungan antara pengetahuan dengan perilaku seks bebas antara lain :

Tabel 4. Tabel Silang Hubungan antara pengetahuan dengan perilaku seks bebas di Tangerang selatan

\begin{tabular}{ccccccc}
\hline \multirow{2}{*}{ Pengetahuan } & \multicolumn{3}{c}{ Perilaku seks bebas } & \multicolumn{2}{c}{ Total } \\
\cline { 2 - 6 } & $\mathrm{N}$ & $\%$ & $\mathrm{~N}$ & $\%$ & $\mathrm{~N}$ & $\%$ \\
\hline Baik & 8 & 4.04 & 190 & 95.06 & 198 & 100.00 \\
\hline Kurang baik & 0 & 0.0 & 12 & 100.00 & 12 & 100.00 \\
\hline \multicolumn{6}{c}{$P$-Value $=1.000$} \\
\hline
\end{tabular}


Berdasarkan hasil penelitian dapat diketahui bahwa responden yang memiliki pengetahuan seks yang baik dan pernah melakukan seks bebas sejumlah $8 \quad(4.04 \%)$, responden yang memiliki pengetahuan yang baik dan tidak pernah melakukan seks bebas sejumlah 190 (95.06\%). Sementara responden yang memiliki pengetahuan yang kurang baik dan pernah melakukan seks bebas sejumlah $0(0.0 \%)$, responden yang memiliki pengetahuan yang kurang baik dan tidak pernah melakukan seks bebas sejumlah 12 (100.00\%). Hasil analisis data pada tabel 4.9 maka didapatkan nilai $P$ Value $=1.000$ dari kemaknaan $\alpha=0.05$, maka $P$-Value $>\alpha$ yang artinya tidak terdapat hubungan yang bermakna antara pengetahuan terhadap perilaku seks bebas.

\section{d. Hubungan antara sikap dengan perilaku seks bebas}

Berikut tabel silang hubungan antara sikap dengan perilaku seks bebas antara lain :

Tabel 5. Tabel Silang hubungan antara sikap dengan perilaku seks bebas di Tangerang Selatan

\begin{tabular}{|c|c|c|c|c|c|c|}
\hline \multirow{3}{*}{ Sikap } & \multicolumn{4}{|c|}{ Perilaku seks bebas } & \multirow{2}{*}{\multicolumn{2}{|c|}{ Total }} \\
\hline & \multicolumn{2}{|c|}{$\mathrm{Ya}$} & \multicolumn{2}{|c|}{ Tidak } & & \\
\hline & $\mathrm{N}$ & $\%$ & $\mathrm{~N}$ & $\%$ & $\mathrm{~N}$ & $\%$ \\
\hline Baik & 4 & 30.77 & 9 & 69.23 & 13 & 100.00 \\
\hline Kurang baik & 4 & 2.03 & 193 & 97.97 & 197 & 100.00 \\
\hline
\end{tabular}

Berdasarkan hasil penelitian dapat diketahui bahwa responden yang memiliki sikap seks yang baik dan pernah melakukan seks bebas sejumlah $4(30.77 \%)$ dan responden yang memiliki sikap yang baik dan tidak pernah melakukan seks bebas

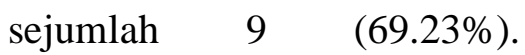
Sementara responden yang memiliki sikap yang kurang baik dan pernah melakukan seks bebas sejumlah 4 $(2.03 \%)$, responden yang memiliki sikap yang kurang 
baik dan tidak pernah melakukan seks bebas sejumlah 193 (97.97\%). Hasil analisis data pada tabel diatas maka didapatkan nilai $P$ Value $=0.000$ dari kemaknaan $\alpha=0.05$, maka $P$-Value $<\alpha$ yang artinya terdapat hubungan yang bermakna antara sikap terhadap perilaku seks bebas.

\section{e. Hubungan antara kepercayaan/agama dengan perilaku seks bebas}

Berikut tabel silang hubungan antara kepercayaan/agama dengan perilaku seks bebas antara lain :

Tabel 6. Tabel Silang hubungan antara kepercayaan/agama dengan perilaku seks bebas di Tangerang Selatan

\begin{tabular}{ccccccc}
\hline \multirow{2}{*}{$\begin{array}{c}\text { Kepercayaan/ } \\
\text { agama }\end{array}$} & \multicolumn{3}{c}{ Perilaku seks bebas } & \multicolumn{3}{c}{ Total } \\
\cline { 2 - 5 } & $\mathrm{N}$ & $\%$ & $\mathrm{~N}$ & $\%$ & $\mathrm{~N}$ & $\%$ \\
\hline Baik & 8 & 3.81 & 202 & 96.19 & 210 & 100.00 \\
\hline Kurang baik & 0 & 0 & 0 & 0 & 0 & 0 \\
\hline
\end{tabular}

Berdasarkan hasil

penelitian dapat diketahui

bahwa responden yang

memiliki kepercayaan/agama

yang baik dan pernah

melakukan seks bebas

sejumlah $8 \quad(3.81 \%)$ dan

responden yang memiliki

kepercayaan/agama yang baik

dan tidak pernah melakukan

seks bebas sejumlah 202
$(96.19 \%)$

Sementara responden yang memiliki kepercayaan/agama yang kurang baik dan pernah melakukan seks bebas sejumlah $0(0 \%)$, responden yang memiliki kepercayaan/agama yang kurang baik dan tidak pernah melakukan seks bebas sejumlah $0(0 \%)$. 


\section{f. Hubungan antara peran orang tua dengan perilaku seks bebas}

Berikut tabel silang hubungan antara peran orang tua dengan perilaku seks bebas antara lain :

Tabel 7. Tabel Silang hubungan antara peran orang tua dengan perilaku seks bebas di Tangerang Selatan

\begin{tabular}{cccccccc}
\hline \multirow{2}{*}{ Peran orang tua } & \multicolumn{4}{c}{ Perilaku seks bebas } & \multicolumn{2}{c}{ Total } \\
\cline { 2 - 6 } & \multicolumn{3}{c}{ Ya } & \multicolumn{3}{c}{ Tidak } & \multicolumn{2}{c}{ N } \\
\cline { 2 - 7 } & $\mathrm{N}$ & $\%$ & $\mathrm{~N}$ & $\%$ & 0 & 0 \\
\hline Baik & 0 & 0 & 0 & 0 & 0 & 0 \\
\hline Kurang baik & 8 & 3.81 & 202 & 96.19 & 210 & 100.00 \\
\hline
\end{tabular}

$\begin{array}{llll}\text { Berdasarkan } & \text { hasil } & \text { Sementara responden yang } \\ \text { penelitian dapat diketahui } & \text { memiliki peran orang tua } \\ \text { bahwa responden yang } & \text { yang kurang baik dan pernah } \\ \text { memiliki peran orang tua } & \text { melakukan seks bebas } \\ \text { yang baik dan pernah } & \text { sejumlah } 8 \text { (3.81\%), } \\ \text { melakukan seks bebas } & \text { responden yang memiliki } \\ \text { sejumlah } 0 \quad(0 \%) \text { dan } & \text { peran orang tua yang kurang } \\ \text { responden yang memiliki } & \text { baik dan tidak pernah } \\ \text { peran orang tua yang baik dan } & \text { melakukan seks bebas } \\ \text { tidak pernah melakukan seks } & \text { sejumlah } 202 \text { (96.19\%). } \\ \text { bebas sejumlah } 0 \text { (0\%). } & & \end{array}$

\section{DISKUSI}

1. Hubungan antara jenis kelamin dengan perilaku seks bebas

Jenis kelamin adalah perbedaan antara perempuan dengan laki-laki secara biologis sejak seseorang lahir.

Berdasarkan hasil penelitian dapat diketahui bahwa responden yang berjenis kelamin laki-laki dan pernah melakukan seks bebas sejumlah 5 (9.43\%) dan responden yang berjenis kelamin laki-laki dan tidak pernah melakukan seks bebas sejumlah 48 (90.57\%).

Sementara responden yang berjenis kelamin perempuan dan pernah melakukan seks bebas sejumlah 3 (1.91\%), responden yang berjenis kelamin perempuan dan tidak pernah melakukan seks bebas sejumlah 154 (98.09\%). Hasil analisis data pada tabel 4.7 
maka didapatkan nilai $P$-Value $=$ 0.039 dari kemaknaan $\alpha=0.05$, maka $P$-Value $<\alpha$ yang artinya terdapat hubungan yang bermakna antara jenis kelamin terhadap perilaku seks bebas.

Penelitian ini sejalan dengan penelitian yang dilakukan oleh Susanti tahun 2012 yang berjudul "Hubungan jenis kelamin, keterpaparan media dan pengaruh teman sebaya dengan perilaku seksual remaja" secara signifikan ada hubungan antara jenis kelamin dengan perilaku seksual remaja $(P$-Value $=0.037)$.

Hal ini dikarenakan adanya kesamaan bahwa status demografi dalam hal ini jenis kelamin berpengaruh dalam perilaku seks bebas. Dimana hasil uji statistik didapatkan bahwa laki-laki berpeluang 5 kali untuk seksual dibanding perempuan.

\section{Hubungan antara usia dengan perilaku seks bebas}

Usia satuan waktu yang mengukur waktu keberadaan suatu benda atau mahkluk, baik yang hidup maupun yang mati. Seperti umur manusia dikatakan lima belas tahun diukur sejak dia dilahirkan hingga waktu umut itu dihitung. Iabel Usia atau umur adalah variabel yang selalu diperhatikan di dalam penyelidikan-penyelidikan epidemiologi.

Berdasarkan hasil penelitian dapat diketahui bahwa responden yang berusia 17-19 tahun dan pernah melakukan seks bebas sejumlah 3 (3.90\%) dan responden yang berusia 17-19 tahun dan tidak pernah melakukan seks bebas sejumlah 74 (96.10\%).

Sementara responden yang berusia 20-24 tahun dan pernah melakukan seks bebas sejumlah 5 $(3.76 \%)$ dan responden yang berusia 20-24 tahun dan tidak pernah melakukan seks bebas sejumlah 128 (96.24\%). Hasil analisis data pada tabel 4.8 maka didapatkan nilai $P$-Value $=1.000$ dari kemaknaan $\alpha=0.05$, maka $P$ Value $>\alpha$ yang artinya tidak terdapat hubungan yang bermakna antara usia terhadap perilaku seks bebas.

Penelitian ini sejalan dengan penelitian yang dilakukan oleh Mahmudah dkk tahun 2016 yang berjudul "faktor-faktor yang berhubungan dengan perilaku seks 
pada remaja di kota Padang" secara signifikan tidak adanya hubungan antara usia responden dengan perilaku seks pada remaja $(P$-Value $=0.689)$.

Hal ini mungkin disebabkan oleh faktor lain seperti pengawasan dari orang tua yang kurang sehinnga mereka bebas melakukan apapun atau karena pengaruh teman sebaya ataupun lingkungan. Jika lingkungan sekitar mendukung remaja memiliki perilaku seksual beresiko.

\section{Hubungan antara pengetahuan} dengan perilaku seks bebas

Pengetahuan merupakan hasil dari tahu, dan ini terjadi setelah orang melaksanakan pengindraan terhadap suatu objek tertentu, pengindraan terjadi melalui panca indara manusia, yakni panca indra penglihatan, pendengaran, penciuman, rasa dan raba.

Berdasarkan hasil penelitian dapat diketahui bahwa responden yang memiliki pengetahuan seks yang baik dan pernah melakukan seks bebas sejumlah 8 (4.04\%), responden yang memiliki pengetahuan yang baik dan tidak pernah melakukan seks bebas

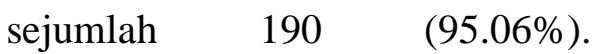
Sementara responden yang memiliki pengetahuan yang kurang baik dan pernah melakukan seks bebas sejumlah 0 $(0.0 \%)$, responden yang memiliki pengetahuan yang kurang baik dan tidak pernah melakukan seks bebas sejumlah 12 (100.00\%). Hasil analisis data pada tabel 4.9 maka didapatkan nilai $P$-Value $=$ 1.000 dari kemaknaan $\alpha=0.05$, maka $P$-Value $>\alpha$ yang artinya tidak terdapat hubungan yang bermakna antara pengetahuan terhadap perilaku seks bebas.

Penelitian ini sejalan dengan penelitian yang dilakukan oleh Minah dkk tahun 2012 yang berjudul "faktor-faktor yang berhubungan dengan perilaku seks pada remaja didesa Susukan Kecamatan Subang" secara signifikan tidak ada hubungan antara pengetahuan responden dengan perilaku seks pada remaja $(P$-Value $=0.328)$. Hal ini dikarenakan adanya kesamaan pola pengetahuan pada kelompok pola pengetahuan pada kelompok remaja yang memiliki pengetahuan yang baik dan 
kelompok yang memiliki

pengetahuan yang kurang baik

antara kedua kelompok tidak berbeda secara bermakna.

Walaupun secara teori pengetahuan dengan perilaku seks bebas mempunyai hubungan yang positif, dimana semakin baik pengetahuan maka semakin rendah perilaku seks pada remaja.

\section{Hubungan antara sikap dengan} perilaku seks bebas

Sikap merupakan reaksi atau respons seseorang yang masih tertutup terhadap suatu stimulus atau objek. Dari batasan-batasan yang ada bahwa manefistasi sikap itu ditafsirkan terlebih dahulu dari perilaku yang tertutup.

Berdasarkan hasil penelitian dapat diketahui bahwa responden yang memiliki sikap seks yang baik dan pernah melakukan seks bebas sejumlah 4 (30.77\%). Dan responden yang memiliki sikap yang baik dan tidak pernah melakukan seks bebas sejumlah 9 $(69.23 \%)$. Sementara responden yang memiliki sikap yang kurang baik dan pernah melakukan seks bebas sejumlah 4 (2.03\%), responden yang memiliki sikap yang kurang baik dan tidak pernah melakukan seks bebas sejumlah $193(97.97 \%)$. Hasil analisis data pada tabel 4.10 maka didapatkan nilai $P$-Value $=0.000$ dari kemaknaan $\alpha=0.05$, maka $P$ Value $<\alpha$ yang artinya terdapat hubungan yang bermakna antara sikap terhadap perilaku seks bebas.

Penelitian ini sejalan dengan penelitian yang dilakukan oleh Desi kumalasari tahun 2014 yang berjudul "hubungan pengetahuan dan sikap dengan perilaku seksual pada siswa SMK" secara signifikan ada hubungan antara pengetahuan responden dengan perilaku seks pada remaja $(P$ Value $=0.000)$.

Hal ini dikarenakan adanya kesamaan bahwa sikap merupakan predisposisi (penentu) yang memunculkan adanya perilaku yang sesuai dengan sikapnya. Sikap tumbuh di awali dari pengetahuan yang disersepsikan sebagai suatu hal yang baik maupun tidak baik, kemudian di internalisasikan kedalam dirinya. 


\section{Hubungan}

antara

kepercayaan/agama

dengan

\section{perilaku seks bebas}

Agama suatu tata kepercayaan atas adanya yang agung di luar manusia, dan suatu tata penyembahan kepada yang agung tersebut, serta suatu tata kaidah yang mengatur hubungan manusia dengan yang Agung, hubungan manusia dengan manusia dan hubungan manusia dengan alam yang lain, sesuai dengan tata kepercayaan dan tata penyembahan tersebut.

Berdasarkan hasil penelitian dapat diketahui bahwa responden yang memiliki kepercayaan/agama yang baik dan pernah melakukan seks bebas sejumlah $8(3.81 \%)$ dan responden yang memiliki kepercayaan/agama yang baik dan tidak pernah melakukan seks bebas sejumlah 202 (96.19\%). Sementara responden yang memiliki kepercayaan/agama yang kurang baik dan pernah melakukan seks bebas sejumlah 0 $(0 \%)$, responden yang memiliki kepercayaan/agama yang kurang baik dan tidak pernah melakukan seks bebas sejumlah $0(0 \%)$.

\section{Hubungan antara peran orang tua dengan perilaku seks bebas}

Peran orang tua memiliki tanggung jawab untuk mendidik, mengasuh dan membimbing anakanaknya untuk mencapai tahapan tertentu yang menghantarkan anak untuk siap dalam kehidupan bermasyarakat. Peran orang tua menjadi hal yang penting dalam pembentukkan perilaku seseorang terlebih itu untuk perilaku anakanak mereka.

Berdasarkan hasil penelitian dapat diketahui bahwa responden yang memiliki peran orang tua yang baik dan pernah melakukan seks bebas sejumlah $0(0 \%)$. Dan responden yang memiliki peran orang tua yang baik dan tidak pernah melakukan seks bebas sejumlah $0 \quad(0 \%)$. Sementara responden yang memiliki peran orang tua yang kurang baik dan pernah melakukan seks bebas sejumlah 8 (3.81\%), responden yang memiliki peran orang tua yang kurang baik dan tidak pernah 
melakukan seks bebas sejumlah

$202(96.19 \%)$.

\section{SIMPULAN}

Adapun simpulan dari penelitian ini adalah sebagai berikut:

1. Terdapat hubungan jenis kelamin dengan perilaku seks bebas pada mahasiswa di Tangerang Selatan dengan hasil analisis data pada tabel silang maka didapatkan nilai $P$-Value $=0.039$ dari kemaknaan $\alpha$ $=0.05$ maka $P$-Value $<\alpha$.

2. Tidak ada hubungan usia dengan perilaku seks bebas pada mahasiswa di Tangerang Selatan dengan hasil analisis data pada tabel silang maka didapatkan nilai $P$-Value $=1.000$ dari kemaknaan $\alpha$ $=0.05$ maka $P$-Value $>\alpha$.

3. Tidak ada hubungan pengetahuan dengan perilaku seks bebas pada mahasiswa di Tangerang Selatan dengan hasil analisis data pada tabel silang maka didapatkan nilai $P$-Value $=1.000$ dari kemaknaan $\alpha$ $=0.05$ maka $P$-Value $>\alpha$.

4. Terdapat hubungan sikap dengan perilaku seks bebas pada mahasiswa di Tangerang Selatan dengan hasil analisis data pada tabel silang maka didapatkan nilai
$P$-Value $=0.000$ dari kemaknaan $\alpha$ $=0.05$ maka $P$-Value $<\alpha$.

5. Tidak ada hubungan kepercayaan/agama dengan perilaku seks bebas pada mahasiswa di Tangerang Selatan dari hasil penelitian dapat diketahui bahwa responden yang memiliki kepercayaan/agama yang baik dan pernah melakukan seks bebas sejumlah 8 (3.81\%) dan responden yang memiliki kepercayaan/agama yang baik dan tidak pernah melakukan seks bebas sejumlah 202 (96.19\%). Sementara responden yang memiliki kepercayaan/agama yang kurang baik dan pernah melakukan seks bebas sejumlah $0 \quad(0 \%)$, responden yang memiliki kepercayaan/agama yang kurang baik dan tidak pernah melakukan seks bebas sejumlah $0(0 \%)$.

6. Tidak ada hubungan peran orang tua dengan perilaku seksual pada mahasiswa di Tangerang Selatan dari hasil penelitian dapat diketahui bahwa responden yang 
memiliki peran orang tua yang baik dan pernah melakukan seks bebas sejumlah 0 (0\%.). Dan responden yang memiliki peran orang tua yang baik dan tidak pernah melakukan seks bebas sejumlah $0 \quad(0 \%)$. Sementara responden yang memiliki peran

\section{DAFTAR PUSTAKA}

Abdillah, Fuad. Makna Hubungan Seks Bebas Bagi Remaja Yang Belum Menikah Di Kota Surabaya. Jurnal Sosial dan Politik. Departemen Sosiologi, FISIP, Universitas Airlangga

Kumalasari, dewi. 2014. Hubungan Pengetahuan Dan Sikap Dengan Perilaku Seksual Pada Siswa Smk. Skripsi. Lampung. STIKes AISYAH Pringsewu

Lestari, widyati. 2015. Peran Orang Tua Dalam Pendidikan Seks Pada Remaja. Skripsi. Surakarta: Magister Psikologi Universitas Muhammadiyah Surakarta

Notoatmodjo, S. Pendidikan dan Perilaku Kesehatan. Rineka Cipta. Jakarta, 2003

Mahmudah dkk. 2016. Faktor-Faktor Yang Berhubungan Dengan Perilaku Seksual Remaja Di Kota Padang. Jurnal Kesehatan Andalas. Universitas Andalas Padang

Masland, P.R. 2004. Apa yang ingin diketahui remaja tentang seks. Jakarta : Bumi Aksara

Minah dkk. 2014. Faktor-Faktor Yang Berhubungan Dengan Perilaku Seks Pranikah Remaja Di Desa Susukan Kecamatan Sumbang. Jurnal ilmiah kebidanan. Akademi Kebidanan orang tua yang kurang baik dan pernah melakukan seks bebas sejumlah 8 (3.81\%). responden yang memiliki peran orang tua yang kurang baik dan tidak pernah melakukan seks bebas sejumlah $202(96.19 \%)$.

YLPP Purwokerto. Vol.5 No.1. hlm 13-18

Prihatin wuri. 2007. Analisis FaktorFaktor Yang Berhubungan Dengan Sikap Siswa SMA Terhadap Hubungan Seksual (Intercourse) Pranikah Di Kota Sukoharjo Tahun 2007. Proposal tesis. Semarang: Program Pasca Sarjana Universitas Diponegoro

Sumadi Suryabrata. 2000.

Metodologi penelitian. Jakarta: PT Raja Grafindo Persada.

Sumiati, dkk. (2009). Kesehatan Jiwa Remaja dan Konseling. Cetakan pertama. Jakarta.

Susanti. 2012. Hubungan Jenis Kelamin, Keterpaparan Media Dan Pengaruh Teman Sebaya Dengan Perilaku Seksual Remaja Di SMPN 6 Palolo Sulawesi Tengah Tahun 2012. Skripsi. Depok. Universitas Indonesia

Tias, arista. 2015. Hubungan Antara Lingkungan Pergaulan Bebas Dengan Sikap Dan Perilaku Seks Bebas Remaja Di SMK Murni 2 Surakarta. Skripsi. Surakarta: Fakultas Ilmu Kesehatan Universitas Muhammadiyah Surakarta 
